\title{
NATURA PIEKŁA
}

\section{Wstęp}

Piekło istnieje, niezależnie od tego, czy ktoś wierzy w nie, czy też je neguje. Istnienie kary wiecznej jest dogmatem wiary katolickiej. Tę prawdę Bóg objawił, a Kościół katolicki nieustannie ją głosi i przypomina wiernym¹. Nauczanie o karze wiecznego potępienia, jest mówieniem o rzeczywistości nadprzyrodzonej i wiecznej. Niestety nikt na świecie nie jest w stanie wyrazić ani pojąć wielkich prawd wiecznych. Jeśli o niebie Biblia naucza, że ,ani oko nie widział, ani ucho nie słyszało, ani serce człowieka nie zdołało pojąć, jak wielkie rzeczy przygotował Bóg tym, którzy Go miłują" (1 Kor 2,9), to również, tak samo nikt nie zdoła pojąć co czeka niepoprawnych grzeszników ${ }^{2}$. Tak jak nauczanie o niebie, prawda o piekle jest przedstawiona językiem metaforycznym. Wiemy i rozumiemy, że jest to rzeczywistość całkowicie różna od doczesnej. Dlatego to co mówimy i myślimy o potępieniu wiecznym, jest bardziej niepodobne niż podobne do naszej obecnej rzeczywistości. Fakt ten nie zwalnia nas jednak od próbowania mówienia i poznawania natury owej straszliwej możliwości, zwanej piekłem³. Gdy rozważamy naukę o wiecznym piekle często spontanicznie rodzą się w nas niepokojące pytania: Czy da się pogodzić miłosierdzie Boże z wiecznym cierpieniem potępionych? Jeśli wolą Boga jest zbawienie człowieka, to czy może istnieć stan potępienia? Dlaczego potępiony nie może zmienić swego stanu? Jakie kary cierpią potępieni? Pytania te wymagają poważnego potraktowania, chodź odpowiedzi na nie, nie są wcale łatwe ${ }^{4}$. W niniejszym artykule postaramy się odpowiedzieć na wyżej przedstawione problemy, która są wciąż aktualne, gdyż dotyczą człowieka każdych czasów. Odpowiedzi na owe zagadnienia oprzemy na nauczaniu współczesnych teologów dotyczących natury piekła.

\section{Wieczne trwanie piekla}

Z Objawienia biblijnego, na którym opiera się nauczanie Kościoła katolickiego dowiadujemy się, że piekło jest wieczne. Wieczność rozumiana jest jako stan

\footnotetext{
M. Ziółkowski, Eschatologia, Sandomierz 1958, s. 206.

2 L. G. de Segur, Piekło, czy istnieje? Czym jest? Wrocław 1993, s. 35.

3 C. S. Bartnik, Myśl Eschatologiczna, Lublin 2002, s. 209.

4 U. Terrinoni, Po tamtej stronie, Kielce 2007, s. 194-195.
} 
nieprzemijalności, co oznacza natomiast, że cierpienia potępionych nigdy się nie skończą . Prawda o piekle, choć powoduje dużo problemów i kontrowersji, jest w Kościele głoszone od wieków. Pomimo owych trudności, Kościół zawsze nauczał o istnieniu piekła, podkreślając, że jest ono wieczne, podobnie jak wieczne jest niebo ${ }^{6}$. Sam Bóg objawił ludziom wieczność kar piekielnych, które czekają tych, którzy przekraczają Boże przykazania, dane z miłości. Wszędzie w Piśmie Świętym, gdzie jest mowa o piekle, tam zawsze jest zapewnienie o jego wiecznym trwaniu. Wieczne trwanie piekła jest więc prawdą tak niewątpliwą, jak istnienie samego Boga?

$\mathrm{Na}$ temat wieczności piekła mówi się czy też pisze z niemałą trudnością. Dzieje się tak między innymi dlatego, iż człowiek żyjący na tym świecie, jak bardzo byłby nieszczęśliwy, ma jednak nadzieję, że kiedyś, prędzej czy później, jego cierpienie się skończy. Natomiast w wieczności cierpienie nie będzie miało końca, sama myśl o takim stanie budzi trwogę $e^{8}$. Anglikański duchowny John Wenham stwierdza, że „dla osoby wierzącej straszniejsza niż jakiekolwiek cierpienie doczesne jest perspektywa wiecznego, nie kończącego się bólu bez nadziei...”" .

Temat piekła jako wiecznej kary za grzechy nie był pomijany w chrześcijańskiej katechezie. Głoszone przez kaznodziejów wyobrażenia nieskończenie długich cierpień, powodowały w ludziach wiele wątpliwości oraz strach przed Bogiem. Wielu bowiem ludzi widziało w nich zaprzeczenie nieskończonej miłości Boga, jak również przeszkodę w szczęściu zbawionych, przebywających w niebie, widzących cierpienie swoich krewnych i przyjaciół. Aby uwolnić się od owych trudności i wątpliwości trzeba najpierw wyjaśnić chrześcijańskie pojęcie wieczności ${ }^{10}$.

Człowiek, który w momencie śmierci, kończy swe życie na ziemi, nie kończy definitywnie swego istnienia, lecz przechodzi w całkowicie inny wymiar trwania. Ów nowy sposób trwania nie jest już czasoprzestrzenny, lecz pozbawiony wszelkich granic ${ }^{11}$. Trzeba więc podkreślić, iż, wieczność nie jest czasem. Wieczność to nie czas, który składa się z chwil następujących po sobie, oraz tworzących razem minuty, godziny, dni, lata i wieki. W wieczności nie ma bowiem chwil, które następowałyby po sobie i byłyby różne od siebie. Wieczność jest sposobem istnienia, całkowicie różnym od tego na ziemi ${ }^{12}$.

Czym jest wieczność odpowiada papież Benedykt XVI w swojej encyklice Spe Salvi. Papież naucza, iż „wieczność nie jest jednak ciągiem następujących po sobie dni kalendarzowych, ale czymś, co przypomina moment ostatecznego zaspokojenia,

5 T. D. Łukaszuk, Ostateczny los czlowieka i świata w świetle wiary katolickiej, podręcznik wydziatu teologicznego, Papieskiej Akademii Teologicznej w Krakowie, Kraków 2006, s. 264.

6 H. Szmulewicz, Po tamtej stronie życia, Tarnów 2003, s. 139.

7 L. G. de Segur, Piekło..., dz. cyt., s. 53-54.

8 M. Cochem, Cztery sprawy ostateczne, śmierć, sad, piekło, niebo, Gdańsk 1995, s. 158.

9 J. Wenham, Tajemnica zła, Kraków 1997, s. 75.

10 T. Špidlik, Życie po śmierci, Maranatha, Kraków 2009, s. 149.

${ }_{11}$ C. S. Bartnik, Myśl..., dz. cyt., s. 215.

12 L. G. de Segur, Pieklo..., dz. cyt., s. 55. 
w którym pełnia obejmuje nas, a my obejmujemy pełnię. Byłby to moment zanurzenia się w oceanie nieskończonej miłości, w której czas - przed i potem - już nie istnieje...."13.

Wieczność jest więc niepodzielna, jest bowiem cała razem. Jest to obecność niepodzielna oraz ciągle trwająca. Nie ma w niej więc chwil, które łączyłby się z innymi chwilami. Czas jest odpowiednikiem czysto ziemskim, nie mającym żadnego odpowiednika $\mathrm{w}$ wieczności ${ }^{14}$. Dlatego nie należy i nie można wieczności utożsamiać z czasem. Wieczność bowiem nie będzie czasem przedłużającym się w nieskończoność. Wieczność będzie raczej anamneza minionego czasu. Co oznacza, że wszystko czego dokonał człowiek i co się wydarzyło w świecie, nie będzie możliwe do wymazania. Wiąże się z tym fakt, iż każde dobro i każde zło uczynione przez człowieka uzyska wieczną wartość. Błogosławieni w niebie, będą się radowali, widząc dobro, które uczynili, natomiast czyniący zło, nie będą już mogli go cofnąć ani naprawić ${ }^{15}$. Oczywiste jest zatem, że wieczności nie ma czasu na zmianę. Tylko bowiem w czasie, w którym ma się przed sobą dni, miesiące, lata można się zmienić. Natomiast jeśli nie ma się przed sobą ani sekundy, nie można przechodzić z jednego stanu w drugi ${ }^{16}$.

O wieczności możemy zatem powiedzieć, chodź oczywiście bardzo trudno jest to nam zrozumieć naszymi władzami poznawczymi, że „nie ma ani początku, ani też końca. To nieustająca teraźniejszość, która nie przemija" ${ }^{17}$. Nieprzemijalność wynikająca z braku czasu w wieczności, a co za tym idzie możliwości na zmiany, determinuje wolność osoby ludzkiej. Istnieje bowiem jedność między czasem, wolnością i wiecznością. Czas sprawia, że wolność jest możliwa, wolność natomiast daje znaczenie czasowi, zaś wieczność nadaje wolności kształt ostateczny i definitywny ${ }^{18}$. Sama zatem istota wieczności, czyni niemożliwą żadną przemianę, czy to na lepsze, czy na gorsze. Dlatego też męki piekielne nie będą mogły ulec zmianie. Kres bowiem cierpień zakładałby jakąś zmianę. Wynika stąd, że kary piekielne mają charakter wieczny i niezmienny ${ }^{19}$.

Wieczność piekła można również wytłumaczyć, możnością popadnięcia przez człowieka w stan ostatecznej zatwardziałości. W ów stan zatwardziałości popada człowiek wtedy, gdy dobrowolnie odrzuca, ofiarowany mu przez Boga, dar przyjaźni. Dar ten jest darmowy i dobrowolny, co oznacza, iż człowiek może go nie przyjąć. Bóg natomiast wyznaczył kres ofiarowania owego daru przyjaźni, gdyż nie możliwe byłoby, aby Bóg występował z tym darem bez końca, również po wielokrotnym jego odrzuceniu. Chwila śmierci jest owym momentem kończącym zbawcze zaproszenie

13 Benedykt XVI, encyklika Spe Salvi, Poznań 2007, nr 12.

14 L.G. de Segur, Piekło..., dz. cyt., s. 55.

15 T. Špidlik, Życie..., dz. cyt., s. 149.

16 L. G. de Segur, Piekło..., s. dz., cyt. 55.

17 M. Cochem, Cztery..., dz. cyt., s. 159.

18 P. C. Phan, Śmierć i życie wieczne, Warszawa 1999, s. 43.

19 L. G. de Segur, Piekło..., dz. cyt., s. 55. 
Boga. Dlatego człowiek, który odrzucił zaproszenie Boga, na wieki traci prawo do przyjaźni z Nim i zostaje od Boga definitywnie oddalony ${ }^{20}$.

Tajemnica wiecznego potępienia budzi sprzeciw i odrzucenie u wielu ludzi. Przykładem mogą być świadkowie Jehowy, którzy odrzucają biblijną naukę o karze wiecznej. Ludzie ci, kierują się przy tym fałszywym przekonaniem, że dobroć Boga nie może skazać nikogo na karę trwającą wiecznie. Wina człowieka jest bowiem aktem ograniczonym czasowo, dlatego nie można jej karać wiecznym potępieniem. Takie poglądy, są jednak całkowicie sprzeczne z nauką płynącą z objawienia biblijnego. To nie Bóg zsyła do piekła, lecz sam człowiek w swej wolności wybiera piekło, które jest wieczne. Jezus przecież w swym przepowiadaniu mówi wyraźnie o wiecznym piekle: „Lepiej jest dla ciebie wejść do życia ułomnym lub chromym, niż z dwiema rękami lub dwiema nogami być wrzuconym w ogień wieczny" (Mt 18,8)21.

Sprzeciw i niezrozumienie istoty wiecznego potępienia jako wyboru człowieka a nie kary Bożej sprawiły, że w ciągu wieków powstało wiele teorii negujących wieczność piekła. Przykładem niech będzie teoria apokatastazy pochodzenia irańskiego, czyli pojednania każdej istoty, nawet Szatana z Bogiem. Według owej teorii piekło, kończące się po pewnym czasie, miałoby tylko funkcję pedagogiczną albo było rodzajem czyśćca. Takie myślenie wykrzywia jednak całą rzeczywistość oraz prowadzi do zatarcia różnicy między dobrem a złem, zbawieniem a niezbawieniem, wiecznością a czasem. Biblijne sformułowania o karze na „wieki wieków” (Ap $14,11)$ są przecież jednoznaczne i bez wątpliwości określają, że stan ten nie skończy się nigdy 22 .

Wypowiedzi Jezusa o piekle, również bardzo jasno wskazują, że jest ono wieczne. Gdyby ktoś twierdził inaczej, to tym samym, podważa autentyczność wszystkich innych wypowiedzi Jezusa. Jeśli słowa o wiecznym piekle mogą wskazywać na coś innego, na przykład, że piekło nie jest wieczne, to również inne wypowiedzi Jezusa mogą nie oznaczać tego, co czytamy ${ }^{23}$. Badając wypowiedzi Jezusa o wiecznym potępieniu, możemy zauważyć ciekawy szczegół. Otóż Jezus, w tym samym zdaniu, mówiącym o wiecznym życiu oraz o wiecznej karze, posługiwał się tym samym przymiotnikiem. Przykładem niech będą słowa Jezusa z Ewangelii według świętego Mateusza: „Idźcie precz ode mnie przeklęci, w ogień wieczny, przygotowany diabłu i jego aniołom" (Mt 25,41), oraz kończące uroczystą wypowiedź, słowa Jezusa: „I pójdą ci na mękę wieczną, sprawiedliwi zaś do życia wiecznego" (Mt 25,46) ${ }^{24}$. Nie możemy zapomnieć również, że wieczność kar piekielnych jest także dogmatem wiary katolickiej. Bóg tę prawdę objawił formalnie i wyraźnie, dlatego z pewnością możemy stwierdzić, że potępieni nie mogą mieć żadnej nadziei, że ich kara kiedyś

20 T. D. Łukaszuk, Ostateczny..., dz. cyt., s. 266.

${ }^{21}$ U. Terrinoni, Po tamtej..., dz. cyt., s. 195.

22 C. S. Bartnik, Myśl..., dz. cyt. s., 265.

23 J. Zieliński, W kręgu Bożych tajemnic. Śmierć, czyściec, niebo, piekło, Kraków 2005, s. 85.

24 J. Wenham, Tajemnica..., dz. cyt., s. 77. 
się skończy ${ }^{25}$. Ową prawdę o karze wiecznej, potwierdził w swym nauczaniu Sobór Watykański II. Na temat wieczności piekła, Sobór wypowiada się w Konstytucji dogmatycznej o Kościele Lumen gentium, w której czytamy: „Ponieważ nie znamy dnia ani godziny, musimy w myśl upomnienia Pańskiego czuwać ustawicznie, abyśmy zakończywszy jeden jedyny bieg naszego ziemskiego żywota, zasłużyli wejść razem $z$ Panem na gody weselne i być zaliczeni do błogosławionych $i$ aby nie kazano nam, jak sługom złym i leniwym, pójść w ogień wieczny, w ciemności zewnętrzne, gdzie będzie płacz i zgrzytanie zębów ${ }^{26}$.

Przyczyną wieczności kar piekła nie jest tylko sam brak czasu w wieczności, lecz również brak łaski. Sam bowiem czas nie wystarcza do tego, żeby się nawrócić. Do nawrócenia konieczna jest także łaska. W życiu ziemskim, Bóg udziela nam łaski do nawrócenia, która staje się początkiem zmartwychwstania. Łaskę jednak można odrzucić, gardząc miłosierdziem Bożym. W wieczności nie będzie już łaski dla grzeszników. Bez łaski natomiast, nie będzie możliwe nawrócenie i odpuszczenie grzechów. Dlatego grzech i następstwo grzechu będą trwały wiecznie, kara też będzie trwać wiecznie $^{27}$. Przez grzech śmiertelny i brak pokuty, człowiek bowiem wykracza przeciwko dobru wiecznemu, niszcząc w sobie życie wieczne w niebie i skazując się na wieczne potępienie. Dlatego o nienawracającym się grzeszniku, można powiedzieć, że jest on wiecznym grzesznikiem, ponieważ w swej woli posiada on stałą gotowość grzeszenia. Stan braku pokuty jest dowodem na możliwość posiadania przez grzesznika takiej woli ${ }^{28}$. Tak więc za grzech śmiertelny, należy się kara wieczna. Wielkość bowiem winy, mierzy się godnością osoby obrażanej. Popełniając grzech ciężki, czyli śmiertelny, obrażamy nieskończonego Boga. Skoro więc Bóg jest nieskończony, to i grzech, którym jest on obrażany, również jest nieskończony i prowadzi do nieskończonej kary. Karę bowiem wymierza się zawsze adekwatnie do zaciągniętej winy ${ }^{29}$.

Mówiąc o wiecznym potępieniu trzeba podkreślić, iż człowiek pozostaje na wieczność w tym, co już wcześniej wybrał. Wraz z chwilą śmierci, możliwość wyboru znika na wieki. Jeśli wybieraliśmy dobro, na wieki będziemy posiadać dobro i życie. Jeśli wybieraliśmy zło i śmierć, na wieki pozostaniemy w śmierci, czyli będziemy potępieni. Będzie tak dlatego, że właśnie tego pragnęliśmy wtedy, gdy jeszcze wolno nam było chcieć, i gdy mieliśmy możliwość wyboru ${ }^{30}$.

Prawda o wieczność piekła jest więc zbudowana na dobrowolnym odrzuceniu przez człowieka Bożego planu zbawienia. Piekło jest w takim wypadku nieodwracalnym stanem odrzucenia Chrystusa ${ }^{31}$. W nauczaniu o wiecznym piekle często po-

25 M. Ziółkowski, Eschatologia..., dz. cyt., s. 224.

26 Sobór Watykański II, Konstytucja dogmatyczna o Kościele, red. M. Przybył, Poznań 2005, nr 48.

27 L. G. de Segur, Piekło..., dz. cyt., s. 56-57.

28 T. D. Łukaszuk, Ostateczny..., dz. cyt., s. 265.

29 M. Ziółkowski, Eschatologia..., dz. cyt., s. 229.

30 L. G. de Segur, Piekło..., dz. cyt., s. 58.

31 H. Szmulewicz, Po tamtej..., dz. cyt., s. 140. 
jawia się zarzut mówiący, że niesprawiedliwością jest, iż można cierpieć wiecznie za grzech, który trwa tylko chwilę. Odpowiadając na powyższe stwierdzenie warto zauważyć, że nie chodzi w tym przypadku o to czy krótko, czy długo trwało przestępstwo, lecz pod uwagę bierze się ciężkość winy. Człowiek, który dobrowolnie popełnił grzech ciężki oraz świadomie w nim trwa, nie pragnąc nawrócenia i nie żałując, ponosi karę nieskończoną. Dzieje się tak, ponieważ poprzez grzech ciężki wystąpił przeciwko nieskończonemu Bogu ${ }^{32}$.

Podsumowując nasze rozważania, należy stwierdzić, iż wieczność możemy zdefiniować jako niezmienny stan poza czasem, który rozpoczyna się w momencie naszej śmierci. Dlatego piekło jako ewentualna pośmiertna możliwość, również jest wieczne, czyli nigdy się nie skończy. To już na ziemi jednak możemy wybrać piekło, gdy całkowicie odrzucamy Boże przebaczenie. Po śmierci ten stan zostanie tylko utrwalony na wieczność.

\section{Natura kar piekła}

W piekle dusze potępione ponoszą podwójną karę. Jest to kara pozbawienia oglądania Boga (poena damni) i kara zmysłów (poena sensus). Każdy bowiem grzech ciężki niesie w sobie podwójną złość: całkowite odwrócenie się grzesznika od Boga oraz zwrócenie się do stworzenia, dlatego to podwójna kara należy się grzesznikowi $^{33}$. Pierwsza kara, czyli zagubienie oglądania Boga, wyraża osobową stronę męki piekielnej, którą oddają słowa biblijne: „Idźcie precz ode mnie, przeklęci, w ogień wieczny" (Mt 25,41). Kara ta jest rozumiana jako skutek negatywnej odpowiedzi człowieka na Boże wezwanie. Kara zmysłów natomiast jest wyrażana w Biblii słowami: „Tam będzie płacz i zgrzytanie zębów” (Mt 25,28) ${ }^{34}$. Wszystkie inne kary wynikają z opisanej powyżej podwójnej kary. Można mówić, że piekło jest także brakiem prawdziwego i rzeczywistego współżycia społecznego, brakiem miłości, a co za tym idzie chaosem i wewnętrznym nieuporządkowaniem, samotnością. Wszystkie wymienione skutki zawierają się jednak w owej podwójnej karze, utracie szczęścia niebieskiego (poena damni) i podleganiu jakiejś nieznanej materialnej karze (poena sensus) $)^{35}$.

\section{Bóg utracony na zawsze}

Jak stwierdza Katechizm Kościoła Katolickiego, ,zasadnicza kara piekła polega na wiecznym oddzieleniu od Boga" ${ }^{36}$. Bóg jest nieskończenie dobry i miłosierny, ale człowiek, który jest obdarzony przez Boga wolną wolą, może nie wybierać miłości

${ }^{32}$ M. Ziółkowski, Eschatologia..., dz. cyt., s. 230.

33 M. Ziółkowski, Eschatologia..., dz. cyt. s. 224.

34 C. S. Bartnik, Myśl..., dz. cyt., s. 209.

35 W. Granat, Eschatologia. Rzeczy Ostateczne Człowieka i Świata, Lublin 1962, s. 224, M. Ziółkowski, Eschatologia..., dz. cyt., s. 219.

36 Katechizm Kościoła Katolickiego, nr 1035. 
i dobra, może nie wybrać Boga. Człowiek, dokonując takiego wyboru skazuje się na odrzucenie ze wspólnoty z Bogiem. Jest to wybór dokonany przez samego człowieka i nie możemy powiedzieć, że to Bóg potępia człowieka, to sam człowiek się potępia, odrzucając Boga i tracąc z nim kontakt ${ }^{37}$.

Życie wieczne możemy opisać jako «widzenie Boga», czyli «bycie razem z Bogiem» i uczestniczenie w Jego bycie. Dlatego wieczne potępienie należy określić jako nie dającym się zmienić stanem oddalenia od Boga i pustką spowodowaną przez to oddalenie. Owo „oddalenie” jest rezultatem grzechu, który niszczy jedność z Bogiem ${ }^{38}$. Współczesna teologia wyraża prawdę, że to właśnie pozbawienie kontaktu z Bogiem będzie najboleśniejszą spośród wszystkich kar piekła. Nikt bowiem z potępionych nie będzie mógł oglądać oblicza Bożego, co będzie tak wielką męką, że na tym świecie człowiek nie pojmie nigdy ogromu tej udręki. Brak możliwości oglądania i przebywania z Bogiem, będzie świadomym doświadczeniem utraty największej miłości ${ }^{39}$, dlatego „niczego potępieni nie będą żałować tak bardzo, jak wiecznego odseparowania od związku z Bogiem"40.

Wszelkie wyobrażenia piekła, gdzie przedstawia się je jako nagromadzenie mąk zmysłowych, nie przedstawiają istotnej prawdy o piekle, i umniejszają jego prawdziwą grozę. Piekło bowiem jest konsekwencją grzechu, jego przedłużeniem, a więc stanem odłączenia się od Boga i to na wieki. To właśnie wieczną utratę Boga, spowodowaną przez grzech trzeba widzieć jako istotę i największy dramat piekła ${ }^{41}$. Po śmierci, gdy zostaniemy uwolnieni z więzów ciała, nasze oczy się otworzą i zobaczymy Boga takim, jakim jest. Ujrzymy wtedy i zrozumiemy, iż Bóg jest najwyższym i bezgranicznym dobrem oraz że największym szczęściem będzie pragnienie oglądania Najwyższego Dobra. Natomiast jeśli ktoś przez swoje grzechy utraci tę możliwość obcowania z Bogiem, cierpieć będzie straszliwy ból, do którego nie można porównać żadnych tortur świata i żadnej ludzkiej niedoli obecnej na świecie ${ }^{42}$.

Należy więc stwierdzić, że „piekło jest gorsze od wszystkiego co znamy. Mo-

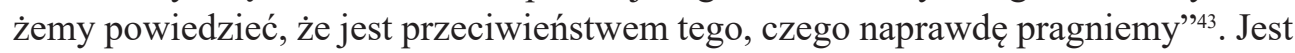
to „miejsce” gdzie nie ma Boga, to znaczy „miejsce”, które to powstało na życzenie człowieka. Piekło to samotność dla tych, którzy odrzucili Boga, bowiem na zawsze pozbawieni są oni oglądania oblicza Bożego ${ }^{44}$. Innym pojęciem określającym istotę piekła jest stwierdzenie, że jest to stan pozbawienia szczęścia niebieskiego. Osiągnięcie nadprzyrodzonego celu polega na oglądaniu Boga, jego miłości i korzystaniu z dobra nadprzyrodzonego. Jeśli natomiast ten cel zostanie utracony, to

${ }^{37}$ C. S. Bartnik, Myśl..., dz. cyt., s. 208.

${ }^{38}$ T. D. Łukaszuk, Ostateczny..., dz. cyt., s. 262.

${ }^{39}$ M. Cochem, Cztery..., dz. cyt., s. 147.

${ }^{40}$ M. Cochem, Cztery..., dz. cyt., s. 148.

${ }^{41}$ T. D. Łukaszuk, Ostateczny..., dz. cyt., s. 262.

${ }^{42}$ M. Cochem, Cztery..., dz. cyt., s. 148.

43 B. Dodds, Przewodnik po niebie, piekle i czyśćcu, Kraków 2002, s. 100.

44 B. Dodds, Przewodnik..., dz. cyt., s. 101. 
owa utrata, pozbawia wszystkiego co było w nadprzyrodzonym celu zawarte, czyli możliwości widzenia Boga, doświadczania jego miłości oraz korzystania z dobra nadprzyrodzonego ${ }^{45}$.

Już Ojcowie Kościoła stwierdzili, iż cierpienie spowodowane utratą nieba jest najstraszniejszą męką potępionych. Utracić bowiem niebo znaczy tyle co utracić Boga ${ }^{46}$. Jako przykład niech nam posłużą słowa św. Jana Chryzostoma, który mówi, iż ,wielu jest takich, co opierając się na fałszywym zdaniu, życzą sobie tylko uwolnić się od piekła; ja zaś sądzę, że o wiele cięższą od piekła karą jest to, że ktoś nie osiągnął tej chwały i stąd wypadł; i sądzę, że nie tak należy boleć nad nieszczęściem piekła, jak nad utraconym królestwem niebieskim"47.

W rozważanej przez nas kwestii utraty Boga, do ciekawych wniosków dochodzi ks. Czesław Stanisław Bartnik. Stwierdza on bowiem, że piekło jest skutkiem podniesienia człowieka do łaski. Można by powiedzieć, że gdyby człowiek nie był przeznaczony do zjednoczenia z Trójcą Świętą, to nie byłoby piekła jako utraty owego zjednoczenia, przebywania z Bogiem ${ }^{48}$. Współcześni teologowie stwierdzają jednoznacznie, że istotą piekła i największą tragedią potępionych jest to, że na wieki są pozbawieni oglądania Boga, bez nadziei na zmianę swego dramatycznego losu. Nie jest to jednak jedyna kara piekielna. Potępieni ponoszą nadto karę zmysłów, o której będziemy mówili w dalszych naszych rozważaniach nad naturą kar piekła ${ }^{49}$.

\section{Kara zmysłu}

W Eschatologii księdza Wincentego Granata kara materialna, zwana karą zmysłu (poena sensus), ,jest to czynnik materialny zewnętrzny w stosunku do potępionych, a będący narzędziem wpływającym ujemnie na ducha lub też ciało" ${ }_{50}$. W Piśmie Świętym Nowego Testamentu znajduje się wiele wyrażeń mówiących o karze materialnej. Najczęściej jest mowa o ogniu, piecu ognistym, gehennie ognia, robaku, który nie umiera, jeziorze gorejącym ogniem i siarką ${ }^{51}$. Cierpienie w piekle jest tak wielkie, że nie można go wypowiedzieć naszymi kategoriami. Jak już wiemy przyczyną owego cierpienia jest oddzielenie od Boga. Jednak brak możliwości zrozumienia i wypowiedzenia dramatu odejścia od Boga, zmusza Pismo Święte do ubogacenia języka obrazami symbolicznymi. Z tych symbolicznych obrazów wyprowadzono w teologii naukę o istnieniu w piekle także kary zmysłów ${ }^{52}$, którą można określić jako: „bólu zadawanego potępionemu przez

\footnotetext{
45 W. Granat, Eschatologia..., dz. cyt., s. 224.

46 M. Ziółkowski, Eschatologia..., dz. cyt., s. 219.

47 M. Ziółkowski, Eschatologia..., dz. cyt., s. 220.

48 C. S. Bartnik, Myśl..., dz. cyt., s.58.

49 M. Ziółkowski, Eschatologia..., dz. cyt., s. 221.

50 W. Granat, Eschatologia..., dz. cyt., s. 225.

51 W. Granat, Eschatologia..., dz. cyt., s. 225.

52 T. D. Łukaszuk, Ostateczny..., dz. cyt., s. 263.
} 
czynnik zewnętrzny i odbieranego przez jego receptory, normalnie zwane zmysłami" ${ }^{53}$. Obrazy ognia i wody wskazują, że nie chodzi w nich tylko o aspekt duchowy, ale również o aspekt materialny. Także nasze ciało, w nie do końca jasny sposób, może uczestniczyć w chwale jak i w cierpieniu ${ }^{54}$. Trudno jest bowiem określić, jaki wpływ ma kara materialna na byty czysto duchowe lub na dusze ludzkie przed złączeniem $\mathrm{z}$ ciałem ${ }^{55}$.

Karę materialną łączono dawniej z działaniem ognia piekielnego, rozumianego w sposób dosłowny: miał to być ogień materialny. Natomiast współczesna teologia uważa ogień za obraz, użyty przez Pismo Święte i nie nadaje mu roli czynnika dręczącego potępionych. Nie sprzeciwia się jednak przy tym pojęciu istnienia kary zmysłów $^{56}$. Dawna teologia biblijne metafory brała zbyt literalnie, dlatego piekło było utożsamiane z jakimś miejscem materialnym, znajdującym się pod ziemią, gdzie płonie materialny ogień. Poglądy takie opierały się po części na przekonaniu, że zło jest w materii. Dzisiejsza teologia nie mówi o piekle jak zresztą również o niebie i o czyśćcu jako o miejscu osobnym. Natomiast w sprawie potępionych, wystarczy przyjąć, że będą to istoty nieszczęśliwe duchowo. Nie należy natomiast uważać, że potępieni będą ciągle prześladowani przez materię i jakieś niekorzystne warunki stworzone przez Boga ${ }^{57}$.

Wartą zauważenia koncepcję kary materialnej przedstawia czeski kardynał ojciec Tomas Špidlik. Stwierdza on, iż ogień Boży objawia się w sercu człowieka jako Duch Święty Ożywiciel, Dawca wiecznego życia. Natomiast człowiek może odrzucić Ducha Świętego, przez co sam wprowadza się w stan duchowego samobójstwa, wybierając śmierć wieczną. Człowiek, dokonując takiego wyboru stwierdza, że jego życie nie będzie mieć sensu oraz że wszystko, co uczynił, i wszystkie przeszłe relacje mają stracić znaczenie. Stan ów może odpowiadać poena sensus, udręce zmysłów, odczuwanej przez stworzenia ${ }^{58}$.

Natura kary materialnej w piekle, zwanej też karą zmysłów, sprawia teologom wiele problemów i trudności. Współczesna teologia odchodzi od dosłownego rozumienia ognia, który symbolizuje karę materialną. Teologowie jednak nie negują faktu istnienia kary materialnej, lecz „nie są zgodni co do kwalifikacji nauki, a ponadto niejednakowo wyjaśniają naturę owego ognia i stosunek do istot duchowych" ${ }^{59}$. Natury męki zmysłów nie da się bowiem definitywnie określić. Objawienie biblijne i Urząd Nauczycielski Kościoła zajmują wstrzemięźliwe stanowisko w odniesieniu

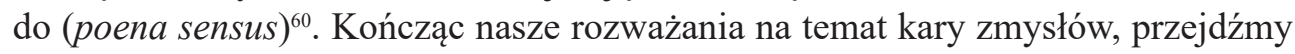

${ }_{53}$ T. D. Łukaszuk, Ostateczny..., dz. cyt., s. 263.

54 Z. J. Kijas, Odpowiedzi na 101 pytań o rzeczy ostateczne, Kraków 2004, s. 262.

55 W. Granat, Eschatologia..., dz. cyt., s. 225.

56 T. D. Łukaszuk, Ostateczny..., dz. cyt., s. 263.

57 C. S. Bartnik, Myśl..., dz. cyt., s. 60.

58 T. Špidlik, Życie..., dz. cyt., s. 147-148.

59 W. Granat, Eschatologia..., dz. cyt., s. 231.

60 U. Terrinoni, Po tamtej..., dz. cyt., s. 194. 
teraz do dalszego opisu natury kar piekła jako istnienia bez miłości. Dalej jednak pozostaniemy w bogatej symbolice biblijnej opisującej piekielne kary.

\section{Niemożliwość kochania i bycia kochanym}

Każdy człowiek, niezależnie od tego, ile ma lat, jakie posiada wykształcenie, czy ile zarabia, pragnie kochać i być kochanym. To właśnie Miłość powołała każdego do istnienia i dlatego tylko w miłości otrzymywanej i darowanej, każdy człowiek może odnaleźć pełnię szczęścia ${ }^{61}$. Piekło, jest zatem stanem odwrócenia się od miłości Boga i innych oraz wyborem wiecznej samotności, w buncie przeciwko Bogu i wszystkim ludziom oraz samemu sobie i stworzeniu. Piekło jest zanikiem jakichkolwiek relacji, utratą kontaktu z innymi, gdzie nie ma już braterskich więzi i przyjaźni, lecz panuje całkowita samotnośćc ${ }^{2}$. Jest bezwzględną pustką i izolacją. Skoro grzech jest zerwaniem więzi z Bogiem i drugim człowiekiem, to piekło jako owoc grzechu jest właśnie stanem odseparowania od Boga i drugiego człowieka. Potępieni są zaprzeczeniem jakiejkolwiek wspólnoty, ponieważ każdy z nich zamyka się całkowicie w swoim egoizmie, tak że już nikogo nie kocha i sam nie jest przez nikogo kochany. Językiem zaś potępionych, staje się zgrzytanie zębów ${ }^{63}$.

Piekło polega nie tylko na wygaśnięciu miłości do Boga, ale również na wygaśnięciu miłości do współbraci. Owa piekielna kara polega na dobrowolnym stanie nienawiści, samotności, zerwania jedności z kimkolwiek. Potępiony, przez nienawiść, samounicestwia się i cierpi w udrękach całkowitej samotności ${ }^{64}$. Piekielny ogień, który płonie, ale nie spala potępionych, symbolizuje brak możliwości spełnienia się człowieka, jego najgłębszych pragnień, z których największym jest tęsknota za miłością. Dlatego w chwili utraty możliwości kochania i bycia kochanym trawi człowieka ogromne cierpienie, które go pali, ale nie spala. Nikt bowiem nie jest w stanie wypalić owej tęsknoty i pragnienia miłości, które każdy człowiek ma w sobie od chwili stworzenia ${ }^{65}$.

Ogień wieczny, może być także rozumiany jako ogień wszechobecności Bożej. Ogień ten dla zbawionych będzie źródłem szczęścia i spotkania z kochającym Bogiem. Natomiast dla potępionych będzie to ogień wiecznego sensu, przed którym będą chcieli uciec, co będzie w rzeczy samej pragnieniem, aby Bóg przestał być wszechobecny. Dlatego stan potępienia będzie stanem wielkiej nienawiści do Boga i niemożliwym do zrealizowania pragnieniem, aby Bóg przestał być Bogiem ${ }^{66}$. W piekle, potępionych spalać będzie wewnętrzny konflikt. Jest to konflikt między dobrem a złem, miłością i nienawiścią, prawdą i fałszem, który w ostateczności jest

\footnotetext{
61 Z. J. Kijas, Piekło, oddalenie od domu Ojca, Kraków 2002, s. 319-320.

62 U. Terrinoni, Po tamtej..., dz. cyt., s. 193.

63 T. D. Łukaszuk, Ostateczny..., dz. cyt., s. 264.

${ }^{64}$ C. S. Bartnik, Myśl..., dz. cyt., s.59.

65 Z. J. Kijas, Piekło..., dz. cyt., s. 320.

66 J. Salij, Bóg na zawsze utracony, „Ateneum Kapłańskie” 1982, nr 439, s. 234.
} 
konfliktem między Bogiem i szatanem. To właśnie z braku miłości człowiek potępiony jest $\mathrm{w}$ konflikcie $\mathrm{z}$ samym sobą, przeżywa owo wewnętrzne rozdarcie $\mathrm{i}$ jest szarpany przeciwieństwami ${ }^{67}$.

\section{Nieskończona milość Boga i wieczne potępienie}

Skoro Bóg jest Miłością, jak czytamy w Biblii, piekło nie powinno być możliwe, Kościół jednak naucza o realnej możliwości potępienia wiecznego. Teologowie proponują na ten problem spojrzeć od innej strony. Pełna refleksja nad życiem wiecznym oraz możliwością potępienia wiecznego powinna być dokonywana w świetle Bożej miłości. Życie wieczne szczęśliwe lub potępione, zależy bowiem od przyjęcia lub odrzucenia Bożej miłości ${ }^{68}$. Bóg jest pełen miłości i miłosierdzia nawet w stosunku do grzeszników. W rozmowie Chrystusa z Nikodemem, sam Jezus wyjaśnia, że Bóg nie chce potępienia człowieka, ale jego zbawienia: „Albowiem Bóg nie posłał swego Syna na świat po to, aby świat potępił, ale po to, by świat został przez Niego zbawiony (J 3,17)". Rozważając prawdę o wcieleniu się Syna Bożego i dokonanego przez Boga dzieła odkupienia, możemy dojść do wniosku, że Bóg nie chce ani grzechu, ani wiecznego piekła, lecz pragnie wiecznego szczęścia człowieka ${ }^{69}$.

Prawda o nieskończonej miłości Boga, nie zaprzecza jednak istnieniu piekła. Bóg bowiem do tego stopnia kocha i ufa człowiekowi, że obdarzył go wolną wolą, dzięki której człowiek może wybierać jak będzie wyglądało jego życie na ziemi i w wieczności. Bóg nie może obdarzyć człowieka wiecznym szczęściem na siłę, wbrew jego woli, wybór zawsze należy do człowieka ${ }^{70}$. Miłość Boża nie znosi bowiem naszej wolności, lecz jest ona darem. Miłość natomiast, która jest darem, wymaga przyjęcia. Prawdą jest, że Bóg, który jest Miłością może tylko kochać i tylko miłość jest możliwa dla Boga. Człowiek jednak w sposób wolny może odrzucić ową Miłość ${ }^{71}$.

Możliwość odejścia człowieka od Boga, możliwość wiecznego potępienia człowieka, nie ma nic wspólnego z brakiem Bożej Miłości. Bóg zawsze kocha człowieka, nawet gdy człowiek odwraca się od Niego. Bóg jednak jest bezsilny wobec ludzkiego wyboru ${ }^{72}$. Niezwykłą prawdą jest, że „Bóg nigdy nie przestaje kochać, nawet jeżeli sam nie jest kochany; ale można Go już nie kochać, podczas gdy On jeszcze kocha, i stąd może się zdarzyć, że postawimy Boga wobec absolutnego przeciwieństwa Jego samego" "73.

Gdy patrzymy na biblijny obraz „syna marnotrawnego" możemy zauważyć, że to nie Bóg odłącza się od człowieka, lecz że to właśnie człowiek opuszcza i porzuca

${ }^{67}$ Z. J. Kijas, Piekto..., dz. cyt., s. 320.

${ }^{68}$ U. Terrinoni, Po tamtej..., dz. cyt., s. 189.

69 W. Granat, Eschatologia..., dz. cyt., s. 203-204.

70 S. Mrozek, Ostateczny los człowieka, Kraków 2009, s. 95.

${ }^{71}$ G. Martelet, Odnaleźć życie pozagrobowe, Kraków 1985, s. 178.

72 S. Mrozek, Ostateczny..., dz. cyt., s. 95-96.

${ }^{73}$ G. Martelet, Odnaleźć..., dz. cyt., s. 178-179. 
Boga, szukając szczęścia poza Nim. Biblia poucza nas, że Bóg nikogo nie prześladuje, gdyż pragnieniem Boga jest szczęście stworzenia. Bóg natomiast szanuje ludzkie wybory i pozwala w nich trwać ${ }^{74}$.

W sposób miarodajny na temat Miłości Boga i możliwości wiecznego potępienia wypowiedział się błogosławiony Jan Paweł II, podczas jednej ze swych audiencji papież Jan Paweł II stwierdził, że „Bóg jest nieskończenie dobrym i miłosiernym Ojcem. Jednakże człowiek, który ma Mu udzielić odpowiedzi w sposób wolny, może niestety dokonać wyboru ostatecznego odrzucenia Jego miłości i przebaczenia i w ten sposób pozbawić się na zawsze radosnej komunii z Nim. Właśnie na tę tragiczną sytuację wskazuje doktryna chrześcijańska, kiedy mówi o potępieniu lub piekle"75.

Łatwiej będzie zrozumieć czym jest piekło dopiero gdy człowiek uświadomi sobie, jak wielka i nieskończona jest miłość Boga do swego stworzenia. W świetle bowiem tego stwierdzenia, na piekło zasługuje stworzenie, które dobrowolnie odrzuca i zamyka się na miłość Boga. Piekło jest dobrowolnym pozbawieniem się owej jedynej miłości, która może dać człowiekowi wieczne szczęście. Odrzucając miłość, człowiek sam pozbawia się szczęścia wiecznego ${ }^{76}$. Tak więc nie da się pojąć piekła i grzechu, nie biorąc pod uwagę straszliwej możliwości odmowy miłości. Nie chodzi jednak o Boga odmawiającego miłości. Nie ma bowiem i nigdy nie będzie człowieka, który byłby nie kochany przez Boga. Gdyby bowiem taka ewentualność zaistniała, Bóg byłby przez ten fakt unicestwiony ${ }^{77}$. Dlatego więc jeśli jakaś istota może zostać potępiona, to dzieje się tak, że „nieskończona Miłość, która się oddała bez żadnych ograniczeń, uznaje się i może się uznać za bezwzględnie odrzuconą"78.

Analizując tajemnicę Bożej miłości, dochodzimy do wniosku, że Bóg, który pragnie szczęścia dla wszystkich, pragnie jednocześnie, aby owego szczęścia chciał także sam człowiek. Bóg obiecał współdziałać z tymi, którzy pragną nieba, lecz nikogo nie zmusza do szczęścia. Bóg nie gwałci wolności człowieka ${ }^{79}$. Widzimy więc, iż oprócz nieskończonej miłości Boga, piekło ukazuje jeszcze jedną tajemnicę. Wielką tajemnicę wolności człowieka, której człowiek nie jest w stanie pojąć. Bóg bowiem tak stworzył człowieka, aby mógł on dokonywać wolnych wyborów. W wolności jednak człowiek może doprowadzić do zatracenia samego siebie i własnego zniewolenia. Prawda o wolnej woli człowieka odkrywa dramat człowieka, który własną decyzją może się potępić80. Przedziwną tajemnicą jest fakt, że „barierą, która może na zawsze oddzielić człowieka od Boga nie jest najcięższy grzech czy zbrodnia, ale ludzka wolność" $"$.

\footnotetext{
74 Z. J. Kijas, Odpowiedzi..., dz. cyt., s. 289-290.

75 Cyt. za B. Dodds, Przewodnik ..., dz. cyt., s. 100.

${ }^{76}$ L. Fanzaga, Spojrzenie w wieczność. Śmierć, Sąd, Piekło, Niebo, Kraków 2002, s. 101.

77 G. Martelet, Odnaleźć..., dz. cyt., s. 179-180.

78 G. Martelet, Odnaleźć..., dz. cyt., s. 180.

79 Z. J. Kijas, Piekło..., dz. cyt., s. 338.

80 L. Fanzaga, Spojrzenie..., dz. cyt., s. 101.

81 S. Mrozek, Ostateczny..., dz. cyt., s. 96.
} 
Mówiąc o piekle zawsze więc trzeba pamiętać, zarówno o wiecznej i niezmiennej miłości Boga do każdego stworzenia, jak i o wiecznym i niezmiennym darze wolności, ofiarowanym każdemu człowiekowi. W takiej sytuacji potępienie i piekło nie mogą być uważane jako chciane i pochodzące od Boga. Bóg bowiem nie powołał do istnienia piekła. Prawda ta jednak nie zmienia faktu, iż człowiek obdarzony wolną wolą, w sposób Bogu tylko wiadomy, może doprowadzić się do wiecznego bankructwa ${ }^{82}$. Człowiek bowiem może wybrać życie albo śmierć, może odrzucić Boga, wybierając grzech i niekochanie. Piekło jest zatem wolnym i świadomym odrzuceniem miłości i jest ono uczynione z odtrąconej miłości. Natomiast człowiek potępiony, sam wyklucza się z troskliwej miłości Boga i zaciąga niewybaczalną winę. Niewybaczalną nie dlatego, że Bóg nie chce mu przebaczyć, ale dlatego, że sam człowiek zamknął się na Boga i nie pozwolił się kochać i przyjąć przebaczenia ${ }^{83}$.

Nauczając o piekle, trzeba jasno stwierdzić, że nie jest ono dziełem potępiającego postępowania Boga, ani też ciemnym podziemnym królestwem, lecz wolnym i obiektywnym wyborem, dokonywanym przez człowieka. Tak rozumiane piekło posiada charakter bardziej duchowy i jawi się jako całkowite i w pełni świadome odrzucenie nieskończonej miłości Bożej. Owe dramatyczne odrzucenie Bożej miłości, jest spowodowane tym, że człowiek nie posiada zdolności do jej przyjęcia, natomiast ów brak zdolności jest skutkiem osobistego grzechu człowieka ${ }^{84}$. Piekło jest zatem związane z grzechem, ,jest ostateczną konsekwencją samego grzechu, zwracającą się przeciw temu, kto go popełnił. Jest to sytuacja, w jakiej nieodwołalnie znajduje się człowiek, który odrzucił miłosierdzie Ojca nawet w ostatniej chwili swego życia" " ${ }^{85}$ Z takiej perspektywy wyłania się prawda, że Bóg nikogo nie potępia. Jeśli zaś człowiek staje się potępiony na wieczność, nie ma w tym winy Boga, lecz winny jest grzesznik, który nie pragnął zbawienia i w swej wolności dokonał wyboru życia bez Boga. Ów wybór można porównać do sytuacji, w której człowiek ucieka przed słońcem do ciemnego pomieszczenia. Słońce nadal świeci, natomiast człowiek dobrowolnie wybiera życie w ciemności. Tak więc konsekwencja odrzucenia Boga jest tragiczna, bo piekielna ${ }^{86}$. Bóg więc nie stworzył piekła, lecz je dopuścił, ponieważ zaakceptował możliwość, że człowiek w swej wolności może odejść od Niego. Z tego wynika, że nie można piekła porównywać z niebem i stawiać na równorzędnym poziomie. Piekło jest marginesem życia, tragiczną możliwością, powstałą na skutek odepchnięcia od miłości Bożej. Niebo natomiast jest chciane przez Boga oraz wyznaczone jako cel dla wszystkich duchowych bytów ${ }^{87}$.

Nauczanie teologów o możliwości wiecznego potępienia, które jest skutkiem wolnej decyzji człowieka ukazuje nam również bezcenność i powagę czasu, w któ-

\footnotetext{
82 Z. J. Kijas, Odpowiedzi..., dz. cyt., s. 272.

${ }^{83}$ U. Terrinoni, Po tamtej..., dz. cyt., s. 192.

${ }^{84}$ Z. J. Kijas, Odpowiedzi..., dz. cyt., s. 272.

85 B. Dodds, Przewodnik..., dz. cyt., s. 100.

86 S. Mrozek, Ostateczny..., dz. cyt., s. 98.

87 W. Granat, Eschatologia..., dz. cyt., s. 204.
} 
rym żyjemy. „Czym zatem jest czas naszego życia, jeżeli nie czasem, który został nam dany po to, abyśmy przyjęli, bądź odrzucili nieskończoną miłość Boga? Gdy zakończy się nasza ziemska wędrówka, Bóg nie zaoferuje nam już swej miłości, skoro wcześniej ją odrzuciliśmy"s8.

W kontekście wolności człowieka i czasu, w którym człowiek może odrzucić Boga, możemy dojść do wniosków, że piekło nie tylko istnieje, ale, że jest również jest dowodem wolności istot duchowych i wartości Dobra. Bogu byłoby może nawet łatwiej unicestwić tych, którzy odstąpili od Niego, niż znosić ich ciągły bunt przeciw sobie. W Bogu jednak nie ma nic z nienawiści, lecz wszystko żyje dzięki Jego dobroci. Dlatego można mówić, iż Bóg nie przestaje kochać tych, którzy na wieki odepchnęli Jego miłość. $Z$ takiej racji Bóg dopuszcza istnienie piekła i toleruje ten stan ${ }^{89}$. Wszystko, co istnieje, zależy od Boga, nie tylko jednak w tym sensie, że Bóg stworzył wszelkie stworzenie i wprawił w ruch jego rozwój. Gdyby Bóg nie utrzymywał wszystkiego w ruchu, to nic by nie istniało. Wszechświat, planeta, kontynent, rzeka, drzewo, człowiek mogą przestać istnieć, jeżeli Bóg przestanie podtrzymywać ich własną egzystencję. Jeśli zatem dusza jest w piekle, Bóg podtrzymuje jej istnienie ${ }^{90}$.

Pozostając w nurcie wyżej przedstawionego nauczania, należy stwierdzić, iż piekło jest postulatem ludzkiej wolności i jego możliwość musi istnieć, jeśli nie chcemy mówić o konieczności zbawienia. Można jednak zapytać na ile człowiek posiada całkowitą wolność decyzji? Każdy człowiek bowiem podlega wpływom wielu czynników, które często warunkują jego decyzje, zawężając pole rozpoznania dobra i zła. Czy zatem ludzka wolność, wśród rożnego rodzaju uwarunkowań, jest wystarczająco zdolna, by Bóg w pełni przyjął czyjąś decyzję na „nie” za wiążącą? Słusznym wydaje się być stwierdzenie, iż na to pytanie człowiek nie może i nie powinien nawet odpowiadać, lecz należy je zostawić głębinom miłosierdzia Bożego ${ }^{91}$.

Dobrym podsumowaniem naszych rozważań na temat wiecznego potępienia w kontekście nieskończonej miłości Boga, niech będzie nauczanie o. Zdzisława Józefa Kijasa. Teolog ten, podzielając naukę Kościoła podkreśla, że Bóg nie stworzył piekła. Początkiem piekła jest bowiem źle wykorzystany dar wolności. Piekło, jak zauważa o. Zdzisław Józef Kijas, jest ryzykiem dla Boga, realną możliwością, jaka wiąże się z ofiarowanym przez Niego darem wolności ${ }^{92}$.

\section{Zakończenie}

W powyższym artykule, zbadaliśmy nauczanie teologów na temat natury piekła. Współcześni teologowie, pozostając w zgodzie z nauczaniem Kościoła wykazali, że piekło jest wieczne. Wieczność piekła wynika z zupełnie innego niż doczesny sposo-

${ }_{88}$ L. Fanzaga, Spojrzenie..., dz. cyt., s. 102.

89 W. Granat, Eschatologia..., dz. cyt., s. 204.

90 B. Dodds, Przewodnik ..., dz. cyt., s. 102.

91 Z. Danielewicz, Traktat o rzeczywistości ostatecznej. Dogmatyka, t. 6, Warszawa 2007, s. 454.

92 Z. J. Kijas, Odpowiedzi..., dz. cyt., s. 290. 
bu pośmiertnego bytowania, gdzie nie ma już czasu, tylko wieczne trwanie w stanie nieba lub piekła. Jednak to już w życiu ziemskim, możemy zapoczątkować ten stan, który tylko utwierdzi się w wieczności. Odrzucając Boga i miłość w życiu codziennym możemy spowodować, że w chwili śmierci nasz wybór zostanie potwierdzony na wieki. Cytowani przez nas autorzy podkreślają, że piekła nie stworzył Bóg, lecz tylko je dopuścił, szanując wolną wolę człowieka, w której ktoś może nie pragnąć Boga. Teologowie wskazują również, iż cierpienie w piekle będzie przede wszystkim spowodowane brakiem miłości, czyli nieobecnością Boga. Brak obecności Boga będzie największą karą dla potępionych. W naszych rozważaniach skupiliśmy się raczej na wskazaniu, że istnieje realna możliwość wiecznego zatracenia. Staraliśmy się również zobaczyć na czym polega istota wiecznej kary piekła. Nie rozstrzygaliśmy natomiast, czy ktokolwiek już znajduje się w stanie owego absurdu.

\section{BIBLIOGRAFIA}

\section{Źródla drukowane:}

Benedykt XVI, Spe Salvi, Poznań 2007.

Katechizm Kościoła Katolickiego, Poznań 2002.

Sobór Watykański II, Konstytucja dogmatyczna o Kościele, red. M. Przybył, Poznań 2005

\section{Opracowania:}

Bartnik C. S., Myśl Eschatologiczna, Lublin 2002.

Cochem M., Cztery sprawy ostateczne, śmierć, sąd, piekło, niebo, Gdańsk 1995.

Danielewicz Z., Traktat o rzeczywistości ostateczne. Dogmatyka, t. 6, Warszawa 2007.

De Segur L. G., Piekło, czy istnieje? Czym jest? Wrocław 1993.

Dodds B., Przewodnik po niebie, piekle i czyśćcu, Kraków 2002.

Fanzaga L., Spojrzenie w wieczność. Śmierć, Sad, Piekło, Niebo, Kraków 2002.

Granat W., Eschatologia. Rzeczy Ostateczne Człowieka i Świata, Lublin 1962.

Kijas Z. J., Odpowiedzi na 101 pytań o rzeczy ostateczne, Kraków 2004.

Kijas Z. J., Piekło, oddalenie od domu Ojca, Kraków 2002.

Łukaszuk T. D., Ostateczny los czlowieka i świata w świetle wiary katolickiej, podręcznik wydziatu teologicznego, Papieskiej Akademii Teologicznej w Krakowie, Kraków 2000.

Martelet G., Odnaleźć życie pozagrobowe, Kraków 1985.

Mrozek S., Ostateczny los człowieka, Kraków 2009.

Phan P. C., Śmierć i życie wieczne, Warszawa 1999.

Salij J., Bóg na zawsze utracony, „Ateneum Kapłańskie” 1982, nr 439, s. 227-235. 
Špidlik T., Życie po śmierci. Maranatha, Kraków 2009.

Szmulewicz H., Po tamtej stronie życia, Tarnów 2003.

Terrinoni U., Po tamtej stronie, Kielce 2007.

Wenham J., Tajemnica zła, Kraków 1997.

Zieliński J., W kręgu Bożych tajemnic. Śmierć, czyściec, niebo, piekło, Kraków 2005. Ziółkowski M., Eschatologia, Sandomierz 1958.

\section{Streszczenie}

Wiara w życie wieczne jest podstawą katolickiej doktryny. Nauka z niej płynąca wskazuje, że ostatecznym losem każdego człowieka jest Śmierć, Sąd Boży, Niebo albo Piekło. Jezus Chrystus głosił, że Królestwo Niebieskie jest przeznaczeniem wszystkich ludzi. Przez swoją mękę, śmierć i zmartwychwstanie otworzył przed nami „bramy nieba” dając każdemu człowiekowi możliwość zbawienia. Każdy człowiek obdarzony darem wolnej woli może, jednakże odrzucić Boga i Jego propozycję zbawienia, skazując się tym samym na potępienie. Stan piekła jak i również nieba jest wieczny i niezmienny. Po śmierci człowiek przechodzi bowiem w zupełnie odmienny sposób bytowania, gdzie nie ma już czasu, jest tylko wieczność. Istotą kary piekła jest brak doświadczenia Boga, brak obecności Boga, który jest wieczną miłością i dobrem. Takie oddzielenie powoduje wieczne cierpienie.

Słowa klucze: piekło, potępienie, eschatologia, życie wieczne, męki piekielne, kara wieczna

\section{The Nature Of Hell}

\section{Summary}

Faith in eternal life is the foundation of Catholic doctrine. The message of this doctrine indicates that the final fate of every human being is Death, God's Judgment, Heaven or Hell. Jesus Christ proclaimed that the Kingdom of Heaven is the destiny of all people. Through his Passion, death and resurrection, he opened the ,gates of heaven" for us, giving everyone the opportunity for salvation. Everyone who has the gift of free will can, however, reject God and His offer of salvation, thus condemning himself. The condition of hell and heaven is eternal and changeless. After death, people pass in a completely different way of life where there is no time, but only eternity. The essence of hell's punishment is the lack of God who is eternal love and goodness. The impossibility of being with God is the cause of eternal suffering.

Key words: Hell, damnation, eschatology, eternal life, torments of Hell, eternal punishment 